\title{
VOZ Y FANTASÍA - LA BÚSQUEDA DE UNIVERSOS IMAGINARIOS Y LA CONQUISTA DE LA FICCIÓN EN ALGUNAS ESCRITORAS ESPAÑOLAS CONTEMPORÁNEAS
}

\author{
“No se debe temer alterar la razón para que se exprese lo intuido; ni penetrar más allá de lo que los sentidos \\ captan para reconocer lo esencial; porque más allá no hay monstruos, sino una mirada distinta para \\ comprender mejor el misterio"
}

(Ana Rossetti, Más allá no hay monstruos)

\begin{abstract}
"Yo escribo también para denunciar una realidad aparentemente invisible, para rescatarla del olvido y de la marginación a la que tan a menudo la sometemos en nuestra vida cotidiana. Porque escribir, para mí, ha sido una constante voluntad de atravesar el espejo, de entrar en el bosque... (...) ...todos y cada uno de nosotros llevamos dentro una palabra, una palabra extraordinaria que todavía no hemos logrado pronunciar. Escribir es para mí la persecución de esa palabra mágica, de la palabra que nos ayude a alcanzar la plenitud; ella es la cifra de mi anhelo"
\end{abstract}

\section{(Ana María Matute, En el bosque)}

“...las hadas han desaparecido con los bosques. En el momento en que se deja de ver la naturaleza no como un ser vivo, sino como un medio de riqueza, no como una fuerza sino como un elemento dominado por el ser humano no se le puede asociar ningún espíritu, ninguna vida propia. Las hadas, según la leyenda, duermen hasta el final de los tiempos, cuando serán necesarias. Como el rey Arturo, como Federico Barbarroja, como el propio Cristo. Esperan su momento para reinar sobre la tierra"

\section{(Espido Freire, Defensa de la fantasía)}

\section{FANTASÍAS DE MUJER}

La marginación de la mujer en el ámbito intelectual ha sido una de las limitaciones fundamentales a las que se ha visto sometida por la imposición del orden simbólico patriarcal. Sin duda, muchas mujeres aceptaron o hubieron de aceptar este patrón que implicaba un modus vivendi muy determinado y que no permitía el desarrollo de su potencial intelectual, al menos libremente. Aquellas mujeres que descubrieron su capacidad y su interés por el saber, que dormía despreciado o desapercibido, se vieron relegadas de diversas formas a la incomunicabilidad de su pensamiento, hasta alcanzar el silencio de la no-escritura y de la no-palabra -como le sucedió a Sor Juana Inés de la Cruz- o derivar en la locura al no soportar esta forma impuesta tan restrictiva de vivir y de pensar, como le sucedió a Virginia Woolf. Descubrir que se posee un mundo propio que se desea compartir y que la presión social niega o rechaza puede resultar insoportable: entonces la persona abandona (muerte espiritual), se suicida (muerte física) o se vive en los límites de la marginalidad. Como veremos, cualquier pretensión creadora en la mujer se ha visto juzgada como algo poco común, incorrecto, desvarío mental, nada serio, y sobre todo antinatural. Ha quedado relegado a la fórmula "pura fantasía de mujer”. Y este concepto tiene su historia y su argumentación filosófica.

\section{LA MUJER IMAGINADA DE OCCIDENTE}

La idea forjada en el imaginario social desde la Edad Media de la mujer ideal como objeto de adoración suprema (la mujer como objeto preciso y sin capacidad para autodefinirse, porque ya es un objeto definido) y como obra magna de Dios en el mundo de la Creación, en el mundo Natural, ha permitido que Naturaleza y Mujer se relacionen con un vínculo inseparable, que complementa y a la vez se opone al de Razón y Hombre (varón). El mundo de la Naturaleza es al menos desde Platón el mundo de los sentidos y de la sensibilidad, de los afectos pero no de las ideas o argumentos. De forma que la mujer, además interpretado su papel por el génesis según San Agustín, se convierte en la compañía humana del varón más adecuada para él, enteramente doblegada a su servicio y supeditada por naturaleza filosófica. Poco a poco la razón se identifica cada vez más 
con el hombre (varón), y la ternura, la afectividad, los sentimientos y la sensibilidad con la mujer, mera complementaria de la razón. Desde Descartes la razón rige definitivamente en Occidente, y se fija bien la idea de que los sentidos la engañan y confunden. De esto parecería concluirse, y es ya un eterno tópico literario y social, que cualquier argumento de mujer, aun sin ella pretenderlo, puede llevar a engaño e inducir a cometer error en el varón, que por sí mismo parece infalible o, en última instancia, perdonable, porque errar sería de sabios. A la mujer se le niega el derecho de razonar competentemente, y resulta menos perdonable que lo pretenda, pues por naturaleza acabaría errando siempre ${ }^{1}$.

Si admitimos que esta es la radiografía de un pensamiento que se ha forjado durante siglos y que está, en todos los niveles de la vida social, resultando muy difícil cambiar, podemos plantearnos seriamente cuál puede ser actualmente la situación de muchas escritoras que lo son o van a serlo. Desde luego subsiste una idea general de incapacidad casi genética y, por tanto, de situación extraordinaria cuando una mujer destaca por encima de otros escritores o intelectuales. Parece que no puede ser lo habitual, y que incluso para lograrlo se haya ayudado de medios cuestionables, al margen de la propia capacidad intelectual. Por lo general, la obra y opiniones de una mujer suelen revisarse, bajo una sistematicidad de tradición histórica, con extremo cuidado, para, finalmente, ser criticadas aprovechando toda una retahíla semántica que afecta a los vicios de la Humanidad y que son atribuidos desde antiguo a todo lo femenino ${ }^{2}$. Resulta muy difícil o imposible romper la dinámica de este pensamiento secular debido a la fuerza con la que es perpetuado mediante estos tópicos, estos lugares comunes que se transmiten de generación en generación, casi desapercibidamente. Parece que la mujer pretende algo que no le corresponde por naturaleza. Parece querer llegar a ser lo que nunca ha sido; esto se interpreta a menudo como una usurpación imperdonable de los roles masculinos, como mera fantasía de mujer, afán de imitar lo admirable masculino; o por el contrario, como una reclamación de un lugar propio en la sociedad ${ }^{3}$.

\section{SENTIDO Y SENSIBILIDAD: LOS ROLES DEL INTELECTO FEMENINO Y LOS IMAGINARIOS POSIBLES DE LA MUJER}

Si volvemos a nuestro razonamiento tradicional, a la mujer lectora o escritora le correspondería principalmente cultivar los afectos en la vida intelectual. Apenas encontrará el lector tratados filosóficos escritos por mujeres: primordialmente poesía lírica y novelitas sentimentales. A grandes rasgos, esto describe la tendencia del siglo XIX y parte del XX, y hoy día el márketing de las editoriales enfoca así la venta de determinadas colecciones y autores. En toda la historia de la literatura, cada escritora además, debe justificar la escritura y publicación de su obra desde su condición de mujer, es algo palpable en todos los prólogos y, en la actualidad, con otro enfoque, en muchas entrevistas. Aunque es cierto que algunas mujeres, como la dieciochesca Margarita Hickey Pellizoni, no dudan en reclamar su individualidad y su mérito al margen de la opinión del sexo opuesto, que permitía o criticaba a su antojo ${ }^{4}$. Emilia Pardo Bazán, con un prestigio internacional reconocido en su tiempo, no logró al fin acceder como miembro de la Real Academia de la Lengua, y era criticada y desfavorecida por sus opiniones feministas, por sus obras o prólogos de tipo ensayístico que publicara, allí donde reclamara la libertad, en especial la educativa, de la mujer ${ }^{5}$. En una España decimonónica

${ }^{1} \mathrm{Al}$ tratar de la naturaleza y comportamiento de la mujer, existe cierta tradición literaria misógina en España, que destaca las escasas virtudes y los muchos vicios de las mujeres, traicionadas continuamente por su naturaleza y que pretenden arrastrar al hombre con sus locuras. Por poner uno de los más antiguos ejemplos, léase el tratadito medieval titulado Corbacho, de Alfonso Martínez de Toledo, Madrid, Cátedra, 1987. Por otro lado, en la Italia renacentista hubo un periodo en que estas ideas se debatieron y se propusieron cambios, incorporando a la mujer cortesana a la vida intelectual, como lo refleja la obra de Baltasar de Castiglione, El Cortesano, Madrid, Cátedra, 1994.

2 Sobre estos aspectos cfr. el interesante ensayo de Laura Freixas, Literatura y mujeres, Destino, 2000.

3 Virginia Wolf realiza una de las primeras y más lúcidas reflexiones feministas sobre ello en su histórico ensayo Una habitación propia, Barcelona, Seix Barral, 1997.

4 El prólogo a sus obras poéticas (Poesías varias, sagradas, morales y profanas o amorosas: con dos poemas épicos, 1779) debió resultar incluso violento para la época. Justifica no haber solicitado el visto bueno de los poemas a algunos amigos eruditos, porque "unos por haberlos contemplado muy afectos, otros por poco, y a los más por suponerlos llenos de preocupación contra obras de mujeres, en las que nunca quieren éstos hallar mérito alguno, aunque esté en ellas rebosando: he desconfiado de la crítica de todos y he escogido por mi único juez al público”. Después de justificar eruditamente el uso y disposición de diversas rimas, el prólogo termina con una rotunda autoafirmación: “Que yo me contento con que no puedan con razón tacharme de impropiedad de estilo, bajeza de expresión y de pensamientos, que son los defectos capitales y esenciales que deben procurarse evitar en tales composiciones; los que, a Dios gracias, no me cuesta gran trabajo ni cuidado huir porque naturalmente me lleva mi genio a cosas altas y nobles, y la expresarlas noblemente.” Véase edición digital en http://cervantesvirtual.com/servlet/SirveObras/875426559626736629127639/p0000001.htm

5 Véase el apasionado e inteligente prólogo a la versión española de Stuart Mill, La esclavitud femenina, versión electrónica: http://cervantesvirtual.com/servlet/SirveObras/430346828416175406227894/p0000001.htm\#1 Cfr. Las siguientes opiniones de reconocidos eruditos sobre ella: "Doña Emilia ha publicado el primer tomo de una nueva novela que no he leído. Pero sí he leído unos apuntes autobiográficos con que la encabeza y que, a mi entender, rayan en los últimos términos de la pedantería...Parece increíble y es para mí muestra patente de la inferioridad intelectual de las mujeres-bien 
con un 90 por ciento de analfabetismo y en la que las novelas destinadas al público femenino eran las novelitas morales y la novela sensible y quizás sentimental era lo menos que se podía reclamar, pues se estaba consolidando a partir de estas novelas un ideal de mujer no muy lejano al propuesto por La perfecta casada de Fray Luis de León. Una mujer sumisa, sensible y, a lo sumo, de arranques sentimentales, pero sobre la que pesaba un control sobre el amor-pasión para que las fantasías producidas por las heroínas románticas de las novelas no fueran a desbocar el comportamiento sexual de la mujer, y, en cadena, todos los demás. En conclusión, la falta de raciocinio adjudicado al poder de los afectos y sentimientos ha de perjudicar la mente y desordenar el mundo moral, basado en reglas y argumentos básicos. Quizás por esa razón, los únicos géneros admitidos tradicionalmente para las mujeres lectoras y escritoras hayan estado además sometidos a una estricta vigilancia, porque aun tratando de afectos, éstos deben ser lo suficientemente ordenados como para no acabar en el vicio -tan femenino de nuevo- de la inmoralidad, de la trasgresión al pecado. Por poner un ejemplo, María de Zayas y Sotomayor, en pleno siglo XVII, no escribió solamente unas novelas amorosas, sino que además debían resultar ejemplares.

\section{LA FANTASÍA INTRASCENDENTE}

Una psicología que solamente se alimenta de sentimientos sin duda se deja llevar por ellos y se ve arrastrada en un proceso que literariamente consumó Emma Bovary y que termina en la inmoralidad y la destrucción del individuo, en este caso la mujer. Este proceso se ve generado porque si a los sentimientos no se les aplica el razonamiento, todo lo que resulta de ello es la elaboración de imágenes sin sentido, es decir, fantasías 6 . De ahí a la locura sólo hay un paso. Por esta razón la fantasía tiene una acepción popular de corte peyorativo, pernicioso, cercano a lo peligroso y subversivo, como "ilusión de los sentidos": de hecho, todo el campo semántico de la ficción se ve amenazado por la incredulidad, por la falsedad de lo no real y, ulteriormente, de lo no útil, y, por ende, de lo no importante, de lo no razonable, de locura. Así que la importancia de cualquier elemento fantástico en nuestras vidas tiende a valorarse estrictamente: la imaginación sólo es buena si se le ofrece sólo un grado exclusivamente lúdico de credibilidad. Y la imaginación de otros mundos se permite sólo así, e implica un mero juego divertido y sin consecuencias al que no se le permite que se infiltre en nuestra forma fundamental de creer o actuar, al igual que tratamos a los niños cuando aplican su fantasía argumental a nuestro mundo, un mundo nuestro construido sobre otras razones muy distintas, pero, quizá, no menos fantásticas o imaginadas ${ }^{7}$.

\section{FANTASÍA POÉTICA, FANTASÍA CREADORA}

Aquí se produce, a mi juicio, una paradoja maravillosa. Hasta ahora las mujeres han llevado el peso, la lacra de la fantasía desbordada e incontrolada debida a su naturaleza sensible: es decir, las mujeres son por naturaleza enormemente receptoras a la producción de fantasías, a escaparse de las razones de este mundo para inmiscuirse en otros, a perder el sentido de esta realidad para crear otras, ilógicas e irracionales para la perspectiva

compensada con otras excelencias-,el que teniendo doña Emilia condiciones de estilo y tanta actitud para estudiar y comprender las cosas, tenga al mismo tiempo un gusto tan rematado y una total ausencia de tacto y discernimiento." (Juan Valera). “A doña Emilia no hay que tomarla por lo serio en este punto ni en muchos otros. Tiene ingenio, cultura y sobre todo singulares condiciones de estilo, pero, como toda mujer, tiene una naturaleza receptiva y se enamora de todo lo que hace ruido, sin ton ni son y contradiciéndose cincuenta veces. Un día se encapricha por San Francisco y otro por Zola.” (Marcelino Menéndez y Pelayo). En : http://www.msu.edu/user/wilso122/critica.htm

6 Fantasía es un concepto aún no muy claro, y en la actualidad tiene significados contradictorios: por una parte como "facultad que tiene el ánimo de reproducir por medio de imágenes las cosas pasadas o lejanas, de representar las ideales en forma sensible o de idealizar las reales”; como "fantasmagoría, ilusión de los sentidos”; o como "grado superior de la imaginación; la imaginación en cuanto inventa o produce”. Cfr. RAE, entrada fantasía. Recuérdese que fantasmagoría significa "ilusión de los sentidos o figuración vana de la inteligencia, desprovista de todo fundamento". Cfr. RAE.

7 La estructura de la realidad en la que se asienta nuestra civilización no está menos inventada que la de una novela. Sus bases son hipótesis científicas que continuamente van cambiando. Los paradigmas de realidad se transforman (Véase como ejemplo del pasado alguno de los ya clásicos libros de KUHN sobre la revolución científica en el Renacimiento) Kuhn, Thomas S. : La revolución copernicana, Planeta - De Agostini, Barcelona, 1994 . Por ello la fantasía adquiere un papel primordial que no se le reconoce. Según la escritora Espido Freire, "una de las funciones primordiales de la literatura es explicar el mundo, y casi todas las explicaciones que conocemos de nuestra existencia son míticas. Inexplicables. No conocemos qué existe después de la muerte, de dónde procede la vida, o el universo, la razón por la que odiamos o nos enamoramos, por qué nos gusta un color, nos hace daño la cebolla o qué hubo antes de que la Tierra existiera. ¿Y tratamos de reflejar la realidad? ¿Qué realidad? ¿La de unas teorías científicas que envejecen y se descartan? Los griegos creían que el órgano vital era el hígado. Hasta hace poco, se pensaba que el corazón. Ahora todo se remite al cerebro. Hasta que descubramos otra cosa. Los anticonceptivos que se vendían como panacea hace veinte años provocaban cáncer, y los implantes de silicona de hace diez también. El SIDA era mortal, y ahora una enfermedad crónica. ¿A qué podemos aferrarnos? ¿A qué verdad? ¿Esa es la fiabilidad de la ciencia, de lo real? Y si eso ocurre en Medicina, o en Física, ¿qué no pasará en literatura?” (Espido Freire, Defensa de la fantasía). 
imperante, la normal, la norma eminentemente masculina. Curiosamente el escritor, el poeta, basa gran parte de su trabajo creador en esta misma premisa, en creer que existen otros mundos que la fantasía descubre y la pluma, posteriormente, revela. $\mathrm{O}$, si el autor es menos creyente, en crear, fabricar esos mundos mediante la ejercitación creadora de la imaginación y la fantasía. Así se podría concluir que, justamente desde el punto de vista del mundo masculino, la mujer debería ser, por su naturaleza sensible, la gran creadora de ficciones dentro del género humano. Las grandes contadoras de historias, cual eternas Scherezades. Pero en general no se olvida que la ficción, por el hecho de serlo, no tiene un alto estatus frente al mundo real, y su importancia es relativa porque su base es la fantasía y no los hechos o la argumentación ${ }^{8}$. Es tinta invisible.

\section{LA FANTASÍA, SENDERO DE PERSPECTIVAS}

Sin embargo, esta paradoja nos permite abrir camino en un mundo como el de la creación de ficciones: la fantasía se abre como un medio, para unos de salir de la realidad, para otros de salir a otras realidades, de encontrarse con ellas. Es decir, de superar algunos de los moldes en los que vivimos y que nos obligan a vivir así, aunque no nos gusten. Es un medio para ponerlos en crisis. Y aquí es donde la mujer, cuando se siente estar determinada por su condición y por el papel de ésta en la sociedad de cada momento, aquí es donde la mujer podría llegar a descubrir otro camino hacia la individuación, hacia la propuesta de nuevas formas de mirar la realidad desde una libertad de perspectiva que le puede llevar a plantear el mundo que desee o el que desearía, o el mundo en el que vive desde su mirada. El encorsetamiento de siglos podría verse raído gracias a un esfuerzo de la fantasía creadora de ficciones y en especial gracias a textos en los que la fantasía ocupe un lugar esencial.

Por ejemplo, aun sin alejarse demasiado de la esfera de lo cotidiano la muy leída y admirada escritora Carmen Martín Gaite ha creado en muchas de sus novelas un ambiente en el que las mujeres protagonistas se descubren a sí mismas de una manera diferente a como la sociedad las ha definido; por ejemplo, en el caso de Nubosidad variable la trama se articula a través de un diálogo epistolar entre dos mujeres que se escriben, en el fondo, a sí mismas, porque no envían nunca sus cartas: pero de manera misteriosa cada carta responde a la anterior y todas ellas reunidas toman un sentido, constituyen un encuentro y construyen, finalmente, la obra de ficción, la historia, la novela.

Desmitificación de los roles tradicionales mediante la subversión creativa de arquetipos

Luego hablaremos del imaginario de género fantástico de Ana María Matute, hasta ahora el mayor esfuerzo de mujer realizado nunca en España por verter un mundo personalísimo sobre el papel, pero hasta entonces estudiaremos tres historias tradicionales antiguas ahora matizadas y reescritas, criticadas con gran humor, por Ana Rossetti, y cuyos finales nos desvelan historias terribles y también posibles nuevas historias. Pertenecen al libro de cuentos Una mano de santos y sus protagonistas son mujeres, niñas.

La primera historia nos cuenta la aventura de una niña bella e inteligente ${ }^{9}$ : "Ella era una niña muy muy guapa. Y muy muy inteligente". Todo el mundo la admiraba por su Belleza externa y su padre se dijo: "No quiero que nadie disfrute sin mi permiso de lo que es mío". Y decidió encerrarla en una torre para que nadie se la robase. "Pero no sabía que es imposible encerrar el entendimiento o la imaginación o el afán de saber". La niña acudió como consuelo "a su Belleza interna, pues explorando a través de sí misma encontraba una posibilidad de escapar". Así, la niña empieza a conocerse a sí misma: "Cuando uno empieza a conocerse empieza a estimarse $y$, entonces, hasta un esclavo puede decidir sobre lo que quiere y lo que debe hacer. Por eso, a quienes les gusta mucho mandar, eso de que la gente estudie les parece muy peligroso porque podría llegar a tener ideas propias y enterarse de lo que es injusto y negarse a obedecer". Por las ventanas altas y estrechas de su torre sólo atisbaba un trozo de cielo y vio en los muros su frontera vital y decidió cambiar su nombre por el de Extranjera, porque esta palabra "viene de extraña, y ella se sentía así. No tanto por ser diferente a los demás, sino porque estaba apartada de los demás". Durante una temporada sólo supo lamentarse de su situación y anotar los días que pasaban, ya que "no podía expresar otra cosa sino su prisión”. Un día descubrió que el terciopelo, según como se aplaste, parece brillante o parece oscuro. Entonces vio que no tenía sentido seguir contando días por contar, pues "no tiene sentido contar lo que no tiene fin", y supo que "las cosas no tienen un

8 Curiosamente, quien acaba reaccionado y razonando así no suele aceptar que la realidad suele superar siempre a la ficción, por increíble que parezca. De hecho, la mayor parte de ficción que se vende en la actualidad está llena de realidades tan cercanas a nuestras vidas que se convierten casi en metas reales: incluso las aparentemente fantasiosas tramas de novela de intriga política internacional no dejan de ser más que simplificaciones literaturizadas (al modelo del folletín decimonónico) de una realidad existente y que posiblemente nos aterraría conocer a fondo porque no nos parecería verosímil, e incluso, real. Es precisamente porque no aceptamos la rica y amplia realidad que nos rodea por lo que hay una abundancia de literatura que está dentro de los límites (sólo jugando con ellos) de lo que aceptamos por razonable y real en nuestra sociedad. Sin ir más lejos, Julio Cortázar no es un autor en absoluto popular entre una mayoría, y su obra se basó en poner en crisis los moldes de los que se alimenta occidente. Quizás porque la fantasía creadora de nuevos modelos altera demasiado el orden al que estamos acostumbrados, y la fantasía es, siempre, amenazadora.

9 Intercalo citas textuales de importancia en el relato con resumen del cuento "La niña extranjera”. Las citas siguientes pertenecen a Ana Rossetti, Una mano de santos, Madrid, Siruela, 1997, pp. 31-39. 
aspecto único". "A partir de entonces, la niña Extranjera decidió que, en vez de lamentarse por ver siempre las mismas cosas, debía tratar de verlas de forma diferente. De todas las formas diferentes que pudiera. Y se dedicó a observar el aspecto cambiante de las cosas inmóviles". Utilizaba pañuelitos y zumo de limón invisible para anotar los resultados de sus pensamientos y descubrió la atención a las cosas "pues, en cualquier parte, la solución está esperando a que la imaginación la encuentre”. Pronto descubrió la lectura, "y los libros se convirtieron en llaves que le abrían continuamente puertas secretas". Mientras tanto su padre estaba buscando un buen candidato entre miles para casar a su hija y, por el momento, "ni corto ni perezoso, mandó a la torre un telegrama anunciando la llegada de un ajuar costosísimo, advirtiendo la conveniencia de que la niña bordase en cada pieza alguna cosita para darse a valer ante los candidatos”. Por supuesto, nuestra niña veía el envés de las cosas y convirtió las mantelerías y sábanas en papel para anotar y escribir, para bordar conocimiento.

Pero dejemos por el momento a nuestra niña Extranjera para conocer a otra niña princesa cuya madre reina decidió ponerle de nombre Poema ${ }^{10}$, ante asombro del padre rey y sus ministros, que "le habían asignado un nombre bien diferente". "-Sí, aseguró la reina-. Un poema transforma la manera de ver el mundo". Y asegura que al convertirse en madre cada día será distinto por depender de la felicidad o tristeza de su hija. Poema era alegre y creativa. "Siempre estaba inventándose juegos. Sus juguetes favoritos eran las palabras; con ellas no se aburría jamás”. Buscaba olores para cada palabra, unía adjetivos y nombres y "observó entonces que, del orden de las palabras, dependía que su corazón se tambalease de alegría o de desasosiego". Todos disfrutaban con sus juegos, extraños para la mayoría, y "desde luego, la reina había acertado en una cosa: la presencia de la princesa Poema todo lo cambiaba y todo lo invadía”. Pero Poema enfermó un día y nadie sabía cómo curarla. La única solución era llevarla más allá de las fronteras del reino, a un lugar desconocido de bárbaros e infieles del que se decía: “Más allá hay monstruos". La princesa Poema partió para tristeza de todos. La acompañaba una escolta de soldados, a los que despidió en la frontera porque Poema pensó que "no quería armas para defenderse, pues estaba dispuesta a conocer. Tampoco necesitaba armas para arrebatar, pues no tenía miedo a pedir”. El reino dejado atrás se sumió en el declive, pero un año después, el 9 de abril, la niña reapareció sana y salva y todos le pedían volver a jugar con las palabras. "Pero para la princesa Poema el lenguaje ya no era un simple pasatiempo, ni cautivarse con la elegancia de su melodía, ni ensayar con la belleza de sus palabras: era penetrar en la conciencia de sus signos". La princesa había cambiado, y, curiosamente, había descubierto que el mundo desconocido y monstruoso no lo era más que su propio reino, pero nadie lo entendía, y pensaban que los monstruos la habían lavado el cerebro. "No piensa como nosotros", "no nos podemos entender con ella". En definitiva, "no les gustaba que hubiera cambiado". Poema visitaba cada tarde las mazmorras reales, donde estaban los prisioneros enemigos del reino, a los que ella ya no veía como monstruos, y los escuchaba. Poema "estaba aprendiendo a 'comprender', es decir: a recibir los reflejos de los otros y contenerlos e incluirlos en su corazón”. La acusaron de traición, porque decían que llevaba alimentos a los prisioneros, pero ante el asombro de todos sólo descubrieron en su regazo una rosa, "la Rosa de los Vientos, con todas las direcciones desde las que se pueden mirar las cosas, pues la realidad no tiene una única manera de mostrarse”. El rey la perdona y reconoce que esa rosa muestra muy opuestas direcciones, aunque él como soberano debe respetar un centro de verdad adonde, a pesar de aquéllas, converger.

Quizás la niña Extranjera del cuento que tenemos pendiente de un hilo de costura, que había descubierto también la perspectiva de las miradas, soñó esta historia como meta ideal, pero su fin fue muy diferente. Un día su padre decidió presentarle a los tres pretendientes escogidos para decidir quién se casaría con ella. Debo transcribir el final del cuento ${ }^{11}$ a pesar de la longitud, porque habla por sí mismo:

"Cuando padre e hija entraron en la biblioteca, los tres pretendientes se levantaron de sus asientos estupefactos. Jamás habían visto una belleza parecida.

-Hija -dijo entonces el padre muy ufano, pues se había dado cuenta de que los tenía en el bote-, éstos son los tres finalistas de entre todos los hombres poderosos y acaudalados que me han pedido tu mano.

-Dices bien: mi mano -respondió la niña Extranjera pausadamente ofreciendo sus dos palmas abiertas-. ¿Y cuál de ellas quieres arrancarme?

-Disculpadla -quiso disimular el padre-, se ha criado fuera del mundo y no entiende que esto no es más que una forma de hablar. Lo que quiero decir, tontita, es que estos caballeros me han pedido permiso para casarse contigo.

-Entiendo perfectamente la frase -dijo la niña Extranjera con gran firmeza-. Lo que no entiendo es por qué tres desconocidos tienen que pedirte permiso a ti para disponer de mi persona.

-Porque yo soy tu padre -repuso el padre fingiendo condescendencia ante las visitas.

-Bien, pues entonces tendría que ser yo, tu hija, quien pidiera consejo a tu experiencia, y a tu amor la bendición, si resolviera casarme o no casarme. Apreciaría tu parecer y agradecería tu aprobación, pero no te

10 Este segundo cuento se titula "Más allá no hay monstruos”, y las citas que intercalo a continuación se comprenden entre las páginas 66-83.

11 “La niña extranjera”, Rossetti, cit., pp. 42-44. 
comprometería en nada más: entiéndelo bien. Porque elegir una norma de vida depende de mi absoluta responsabilidad y no de tu permiso o de tus órdenes.

-No seas insolente -rugió el padre dándole una bofetada.

-Papá, mi obligación para conmigo misma está por encima de los pactos que hayas hecho con ningún extraño.

-Tu única obligación es honrar a tu padre-intervino uno de los pretendientes.

-¿Qué honra podría dar si no tuviera respeto por mi propio honor? Para honrar dignamente, primero hay que ser digno de honrar -contestó la niña Extranjera.

-Honrar o no honrar no hace ahora al caso -se impacientó el segundo pretendiente-. Lo importante es que le obedezcas.

-Una cosa es obedecer, que es un acto de la voluntad, y otra aniquilarse, que es un acto de degradación puntualizó la niña Extranjera cortésmente.

-Señores, es hija única y está un poco mimada, pero una buena tunda de vez en cuando es un remedio infalible para que mantenga cerrado el pico -se apresuró a decir el padre, alarmado de que sus cálculos se fueran a pique.

-Bueno, bueno -dijo el tercer pretendiente tratándola peor que si fuera peor que boba-, con lo guapa que eres no tienes por qué jugar a ser tan razonable. Las niñas marisabidillas se ponen muy feas y se quedan solteronas y amargadas.

-No puedo consentir -estalló entonces la niña Extranjera con extraordinaria vehemencia-, no puedo consentir que se tome la Belleza como pretexto para insultarme en mi inteligencia y en mi libertad.

-Vámonos de aquí -dijeron más o menos los tres pretendientes-: parecía una muñequita andadora y es una bomba de relojería.

-¡Desgraciada! -prosiguió el padre usando como látigo su correa-. Esto te enseñará modales.

-Sé muy bien lo que quieren decir los modales: hablas de conceder mi mano en el lenguaje refinado del mundo, pero el hecho es que me venderás como a una yegua.

-Harás lo que te ordene porque soy tu padre.

-Entre nosotros está la herencia de la sangre y los vínculos de la ley. Pero existe una tercera cosa que es el albedrío, y es más fuerte que las otras dos.

-Te mataré -dijo el padre, fuera de sí.

-Podrás convertir el agua en vapor o en hielo - gritó la niña Extranjera-, pero siempre será Hache-Dos-O.

El padre se precipitó hacia ella y ella escapó al monte y se refugió en una gruta. Pero parte de sus cabellos se quedaron fuera, asomando como pequeñas culebras. Y el padre la descubrió.

Ahora tengo que escribir que el padre, con la media luna de su alfanje, le cortó la cabeza. Y que, cuando el padre bajaba del monte, un fuego misterioso cayó del cielo y lo redujo a cenizas."

La ideología transmitida en el texto es muy clara, pero la autora quiere expresar explícitamente su reivindicación, y tras aclarar que ésta ha sido la historia de santa Bárbara, advierte que "esta historia no es una fábula. Es verdad. Todavía es verdad. Aún hay chicas asesinadas por no llevar velo, por querer estudiar, por pretender dirigir sus propios destinos. Aún hay chicas encerradas en sí mismas confiadas a la tutela de sus padres o de sus maridos porque no pueden decidir. Aún hay chicas a las que se les niega el derecho a desarrollar su inteligencia y a ejercer su libertad. Aún hay chicas silenciadas. Chicas de las que no hablará nadie"12.

En ambas historias, cuando las dos niñas princesas descubren que pueden mirar el mundo de otra manera gracias al conocimiento y al lenguaje (descubren el logos), son rechazadas e incomprendidas por la sociedad que les rodea, se vuelven extrañas para todos, y sólo les queda vivir bajo el signo de la resignación y el acatamiento del orden establecido (le ocurre en cierta medida a Poema) o, de lo contrario, morir sacrificadas, como santa Bárbara.

La escritora Espido Freire, que representa la generación más joven de magas de la palabra en español, ha publicado recientemente un ensayo (que a la vez es cuento) titulado Primer amor, en el que repasa decenas de cuentos populares bien conocidos por todos nosotros y que, tras su análisis, representan los roles que estamos acostumbrados a personificar cuando nos relacionamos con individuos del sexo opuesto. Así, existen las ratitas presumidas, los robin hoods, las princesas del guisante, las cenicientas y blancanieves, etc. La escritora ironiza y pone de relieve cómo estamos mediados por esos modelos ancestrales, la mayoría propios de una visión patriarcal del mundo, y cómo algunos de ellos, a su juicio, no tienen lógica alguna y producen situaciones absurdas. Quiero destacar, por lo que nos atañe aquí, que este ensayo está repleto tanto de fantasía como de sólida argumentación y agudas y oportunas opiniones sobre el tema. ¿Se está abriendo ya la senda?

Queda aún una historia ${ }^{13}$ por repasar: hay una tercera niña princesa rebelde que logra llevar a cabo la proeza de concluir su propia historia con una historia contada por ella misma, una historia que en cierto modo

12 “La niña extranjera”, Rossetti, cit., pp. 44-45.

13 “El dragón y la doncella”, Rossetti, cit., pp. 47-60. 
transforma la propia historia porque la crea, y transforma también la vida de un joven caballero que era el hijo de San Jorge, aquel celebérrimo caballero que mató al dragón y salvó a la princesa, pero no a ésta, porque como veremos, ésta se negó a aceptarlo. "Esto era de cuando las doncellas permanecían en las cuevas de los dragones hasta que un caballero las rescataba. Ninguna estaba allí mucho tiempo, es verdad; a menudo, nada más el dragón comenzaba a descerrajar las mandíbulas, aparecía un caballero, le rebanaba la cabeza al dragón y se llevaba a la doncella para convertirla en buena esposa y prolífica madre de familia. Claro que, a veces, el caballero se retrasaba y entonces la doncella tenía que entretener al dragón". Nuestra doncella sólo había podido traerse un tapiz del palacio para entretener al dragón, e iba destapando un poquito de una esquinita y jugaba con el dragón al veo,veo. Entonces llegó un caballero, que no lo era, "ni muchísimo menos, porque no resaltaba en su armadura ni en su escudo ninguna divisa de caballería”. Pero como al dragón sólo se le puede vencer con la espada de la Verdad y el escudo de la Virtud, ambas otorgadas con la divisa correspondiente, este caballero, a juicio de la princesa, no podría vencer a su dragón. "Detenéos y no oséis introducir vuestra espada en este lugar, pues no está ungida y os puede suceder cualquier desgracia horrible". El caballero insistió varias veces, al más puro estilo de antaño: "Vos merecéis mi suerte, sea cual sea -dijo Jorge, galante." "-A mí no me hagáis responsable de vuestro destino -replicó la doncella, molesta por semejante atrevimiento-. No soy de esa clase de persona". Al fin Jorge desistió, se dirigió a otro lugar, encontró a otra princesa que no puso pegas y mató al dragón. Gracias a esto fue armado caballero y vivieron felices. Pero nuestra anterior princesa se quedó de nuevo a solas con el dragón, esperando un nuevo caballero. Para entretener al animal continuó con el juego del tapiz. Era muy grande para extenderlo por completo en la cueva. Así que lo cortaron en trocitos y unieron los pedazos con imperdibles, formando grupos, como si fueran libros. Cada librito, a través del veo, veo les sugería por las imágenes una historia diferente. Al dragón le encantaba una en la que él era protagonista, vivía en un pantano y atemorizaba a todo un pueblo, que le traía princesas para que se las comiera... pero nunca coincidían en el final. La princesa proponía que él se volvía un buen dragón, pero eso era inaceptable para él. Él quiere devorar a san Jorge y luego a ella, y, posteriormente, si hace falta, la vomita... y así todo. Mientras tanto, el verdadero San Jorge reside en su castillo, pero se acuerda de la princesa a la que no rescató, y se da cuenta de que eso no estuvo bien. Nadie en su familia toma en serio sus lamentaciones, excepto el hijo menor, Jorge. Es joven y fuerte y decide salvar a la princesa, si el dragón no se la ha comido todavía. Roba los blasones de su padre y se presenta allí, pero llega tan cansado que se desploma ante princesa y dragón. Ambos decidieron devolver al caballerito a su casa, y en el palacio se alegraron mucho, pero nadie allí hizo caso de los rescatadores: solamente la gente del pueblo se acercó a la extraña pareja y ellos les contaban la historia del dragón que en un condado llamado Barcelona había causado el pánico... Todos tomaron la historia por verdad y al caballero salvador por el joven Jorge. La doncella, que ya tenía cierta edad, "sabía que el joven no le había dado a su espada el uso debido, pero ya había vivido lo bastante y había urdido suficientes peripecias y sabía que las cosas son verdad cuando se cree en ellas y veía las cosas diferente a como las veía cuando, el Jorge padre, le quiso dar la oportunidad de ser la madre de Jorge hijo. Y decidió que si el chico iba a ser armado caballero ella no pondría obstáculos. Es más, le ayudaría a estrenar su espada mediante cualquier otra prueba que lo hiciera acreedor de un escudo con blasón propio sin necesidad de matar a su amigo el dragón”. Y ella, con "su voz, ejercitada en persuadir y encantar" pidió al joven Jorge que le cortará una flor del jardín con la espada. Fue una rosa blanca que se volvió roja al ser cortada. Ella, a cambio, le regaló el libro hecho de tapices:

“-Tomad. Todo lo que pasó en la cueva está aquí. Ésta es mi declaración.

Y le dio el libro.

-Le falta el final -observó el joven Jorge.

-El final es una rosa roja -fue el comentario de ella."

Princesa y dragón desaparecieron, pero dejaron una historia hermosa de descubrimiento y amistad y una leyenda, la de San Jorge. En este caso, a través de esta revisión/reversión de una historia caballeresca desde el punto de vista de la princesa (gran novedad), la mujer es quien acaba proponiendo una realidad, una historia, un sentido, una leyenda que acaba por convertirse en patrimonio de toda una comunidad. La interpretación de un tapiz (tejido quién sabe si por otra mujer sabia, una secreta Penélope) da lugar a la invención de historias que modifican la realidad, a la vez que desmitifican lo que parece inevitable. Incluso el dragón acaba siendo amigo de la princesa, o al menos, permite cuestionar su papel. La fantasía es, pues, capaz de modificar la visión del entorno en el que vivimos y por esa visión, la propia historia de las cosas y los hombres. No hace falta salvar princesas para ser todo un caballero, no hace falta matar dragones. ¿¿Se lo ha planteado el lector alguna vez?

\section{LA VOZ DEL BOSQUE O LA LLAMADA MÁGICA DEL IMAGINARIO}


Ana María Matute ${ }^{14}$, cuya vida podría asemejarse a la de estas niñas de los cuentos, ha creado en el trasncurso de su vida una voz ejercitada en persuadir y encantar a la que ha sabido unir un imaginario fantástico completo. Nos lo ha mostrado definitivamente con más de setenta años, pero la espera, necesaria, ha merecido la pena: La torre vigía, Olvidado Rey Gudú y, recientemente, Aranmanoth demuestran que el hallazgo de una personalísima voz narrativa y la literatura de fantasía no son en absoluto ajenas. El público ha acogido con entusiasmo estas obras y es la primera vez en la historia de la literatura española que una novela de tipo fantástico se eleva a altísimos niveles de sensibilidad humana y gran calidad literaria. Y que no es reductible estrictamente al consumo infantil. Ana María Matute ha penetrado en el mundo de la fantasía, para ella un bosque inmenso, con el asombro de una niña de siete años, una Alicia a punto de visitar un País de Maravillas tras cruzar el umbral de este mundo hasta el de la ficción.

"El momento en que Alicia atraviesa la cristalina barrera del espejo, que de pronto se transforma en una clara bruma plateada que se disuelve invitando al contacto con las manitas de la niña, siempre me ha parecido uno de los más mágicos de la historia de la literatura, quizá el que ofrece un mito más maravilloso y espontáneo: el deseo de conocer otro mundo, de ingresar en el reino de la fantasía a través, precisamente, de nosotros mismos" (...) "Porque no debemos olvidar que lo que el espejo nos ofrece no es otra cosa que la imagen más fiel y al mismo tiempo más extraña de nuestra propia realidad. Desearía, pues, exhortaros a participar, durante el breve tiempo de este atípico discurso, de la fascinación que sin duda constituye la cifra de mi obra, y acaso también de mi vida: la posibilidad de cruzar el espejo e internarse en el bosque de lo misterioso y de lo fantástico, pero también del pasado, del deseo y del sueño. No pretendo que abandonemos este mundo, nuestro mundo, sino tan sólo que nos aventuremos por unos instantes en los otros mundos que hay en éste ${ }^{15}$."

Para Ana María Matute, la mirada en torno a ella está repleta de fantasía, y ésta forma parte de la esencia de la vida en su totalidad: "Siempre he creído, y sigo creyendo, que la imaginación y la fantasía son muy importantes, puesto que forman parte indisoluble de la realidad de nuestra vida. Cuando en literatura se habla de realismo, a veces se olvida que la fantasía forma parte de esa realidad, porque, como ya he dicho, nuestros sueños, nuestros deseos y nuestra memoria son parte de la realidad. Por eso me resulta tan difícil desentrañar, separar imaginación y fantasía de las historias más realistas, porque el realismo no está exento de sueños ni de fabulaciones..., porque los sueños, las fabulaciones e incluso las adivinaciones pertenecen a la propia esencia de la realidad”.

\section{LA INFANCIA RECUPERADA, LA VOZ PERDIDA EN EL SUEÑO DE LA RAZÓN}

Mediante esta teoría sobre la ficción, que tiene su puesta en marcha práctica en aquel hombre-niño llamado Don Quijote, Ana María Matute reconoce la existencia de una realidad invisible que hay que desvelar y que desde la fantasía y la infancia (es decir, también desde los cuentos infantiles) se hace posible:

“Así de reales eran aquellos mundos en los que me sumergía, porque los llamados «cuentos de hadas» no son, por supuesto, lo que la mayoría de la gente cree que son. Nada tienen que ver con la imagen que, por lo general, se tiene de ellos: historias para niños, a menudo estupidizadas y trivializadas a través de podas y podas «políticamente correctas», porque tampoco los niños responden a la estereotipada imagen que se tiene de ellos”.

Sin duda, nada es lo que parece a nuestros ojos poco atentos en este mundo que empeñamos en considerar fidedignamente real, y quedamos sin percatarnos de ello atrapados por los espejismos en que vivimos; así, los relatos de Ana Rossetti, la novelística fantástica de Ana María Matute son textos de un aparente carácter infantil pero dirigidos sobre todo a adultos que han olvidado ser niños, que perdieron su infancia, su paraíso. Niños perdidos en el mundo de la realidad que abandonaron la fantasía hace mucho tiempo y necesitan volver a ella gracias a las Aguas de la Vida de la Literatura. Una Literatura que para Matute representa “la expresión más maravillosa que yo conozco del deseo de una posibilidad mejor. Para mí, escribir es la búsqueda de esa posibilidad ${ }^{16 ”}$.

14 Ana María Matute, con reconocimiento internacional y eterna candidata al Premio Nobel, ha sido merecedora de numerosísimos premios literarios, proclamada como la mejor narradora de relatos y en la actualidad única mujer escritora miembro de la RAE.

15 Todas las citas de Ana María Matute pertenecen a su discurso de ingreso en la RAE, leído el 18 de enero de 1998 y titulado En el Bosque. Publicado en formato electrónico en: http://www.aragonesasi.com/casal/matute/matute01.htm

16 "Para mí, escribir es la búsqueda de esa posibilidad. Una búsqueda, sin duda. Y, a veces, hasta feroz. Algo parecido a una incesante persecución de la presa más huidiza: uno mismo. Esta búsqueda del reducto interior, esta desesperada esperanza de un remoto reencuentro con nuestro «yo» más íntimo, no es sino el intento de ir más allá de la propia vida, de estar en 


\section{LA NUEVA VOZ}

Y quizás porque su última meta sea encontrar una posibilidad mejor, ninguna de estas escritoras, que defienden sin duda la condición femenina en la que viven, ninguna se define a sí misma exclusivamente como mujer cuando escribe: no son mujeres que se consideran que deben escribir para mujeres, ni consideran necesariamente sus temas como tradicionalmente femeninos. Pero han encontrado su voz, una voz que es de mujer pero que sobre todo es la suya. Y nos han revelado también que la fantasía, las perspectivas nuevas y la libertad ante esos moldes que la razón tradicional nos impone están ligados y tanto Ana Rosetti en los cuentos anteriores como Ana María Matute en sus últimas obras han construido un mundo alternativo (incluso con reivindicación explícita) en el que mostrar, como niñas Extranjeras, su Belleza interior esplendorosamente. Por el momento, si me permiten la ironía, algo se ha ganado, porque a ninguna de las dos se les ha cortado la cabeza, pero tengamos en cuenta que el filo del alfanje pesa todavía y de muchas formas sobre sus gargantas, pues incluso Ana María Matute es la única mujer que pertenece a la Real Academia en la actualidad, entre decenas de académicos, y a Espido Freire aun le preguntan en las entrevistas si tiene novio (El Correo 17-10-1999) y en círculos editoriales acostumbran a llamarla "la niña”(Territorios, 10-11-1999)17.

Sin duda, la utilización de imaginarios fantásticos en el caso de estas escritoras es, en mi opinión, revelador. Primero, les ha permitido utilizar la fantasía para constatar y criticar realidades. Segundo, les ha permitido plantear alternativas creativas, posibilidades. Y tercero, gracias a estos esfuerzos y otros realizados también por escritores, la fantasía puede comenzar a adquirir una importancia mayor en el ámbito literario y cultural español, caracterizado, hasta no hace mucho por un hiperrealismo descarnado. Respecto a esto tenemos el ejemplo de Espido Freire, admiradora declarada de Ana María Matute, que ha reiterado en varias entrevistas que "los escritores españoles son especialistas en describir, en la crónica, en la narración costumbrista y en reflejar la realidad, pero sin hacer uso de la fantasía”(Worldonline.es 10-02-2000). “¿Por qué se nos abren mundos nuevos cuando somos niños, cuando somos jóvenes, y se nos cierran al crecer? ¿Por qué la ficción no es respetable, por qué esa desconfianza hacia la fantasía?” se pregunta Espido Freire en su conferencia titulada Defensa de la fantasía, de la que recortes de prensa destacaron como comentarios que "el imperio absoluto de la novela decimonónica impide la creación de una nueva corriente novelística. Por ello, defiende la literatura de fantasía que ha sido vista de manera despectiva a lo largo del tiempo y ha sido relegada al cuarto de los niños" (Worldonline.es 3-4-2000). "Un inventor no lograría nada si no soñara, si no se encargara de revolucionar lo existente con un artefacto o una teoría inexistente” “¿Por qué limitar la literatura?”18

\section{LA NUEVA VOZ DE LA FANTASÍA O LOS MUNDOS POSIBLES DE LA REALIDAD}

Pero esta defensa de la fantasía a través de la novela es un hecho que se está dando en la actualidad, aún muy tímidamente. No sólo en escritoras, sino también en escritores. Porque el cuento de la niña extranjera, con su feminismo, no acaba en la reivindicación puramente feminista, que, sinceramente, me parece simplemente de básica justicia humana. La propia autora añade al final del relato: "esta no es una historia de chicas y sólo para

las otras vidas, el patético deseo de llegar a comprender no solamente la palabra «semejante», que ya es una tarea realmente ardua, sino entender la palabra «otro».". "En el Bosque”, cit.

17 “ ¿Va a tener tiempo de hacer una tesis? La haré. El estudio de la lengua y la literatura es algo que a larga es muy rentable. Aparte de que con ello le puedes dar en las narices a cualquier persona que me considere una niña que se dedica en sus ratos libres a escribir historias. Es que ahora soy 'La niña'. Para mi agente soy 'La niña'; para los editores soy 'La niña', y los periodistas ya empiezan a llamarme así. A la literatura me dedico muy seriamente” (Territorios, 10-11-1999)

18 Espido realiza así un alegato final denunciando la hipocresía cotidiana de nuestro sentido de la realidad: "Por lo tanto, desconfío de una sociedad que modifica los cuentos infantiles y elimina lobos y madrastras, en un intento de convencer a los niños de que el mal no existe. El mal habita en las calles, en los compañeros que les roban la merienda o en la madre que le castiga sin ver la tele. Desconfío de una sociedad que reniega de lo fantástico pero que se evade mediante deportes, mediante prensa rosa y cotilleos de una realidad que no le agrada. Recelo de quienes se rasgan las vestiduras ante una película violenta o una publicidad agresiva y defienden luego la retransmisión de muertes en directo, de atentados o tragedias. Antes bien, por ser una recreación, por ser ficción, por no ser verdad, deberían tolerarse sin problemas las reproducciones artísticas, y dejar los escrúpulos y el miedo a ofender sensibilidades a la realidad.”

Todo lo justifica el directo, la obtención de la noticia. El ser testigos de algo que no vemos. De ahí el gancho de películas basadas en un hecho real, de los programas de testimonios. ¿Para qué ahondar en una realidad sórdida y tétrica? ¿Qué mérito tiene esa verdad? ¿Qué privilegios para gozar de categoría de arte? ¿Dónde queda la auténtica creación?

Desconfío, por último, de quienes tratan de imponer leyes fijas a la realidad, al arte y la literatura. De quienes no se sienten lo suficientemente seguros como para revisar sus teorías sin alterarse o enfadarse. De quienes desprecian lo que no conocen, lo que no ven, lo que no controlan. Desconfío de quienes matan la imaginación infantil y consideran que para crecer es preciso renunciar a ella. Y contra ellos, en socorro de la magia, de las verdades ocultas, de lo irracional, del misterio y las pesadillas me he embarcado en esta defensa de la fantasía”. Defensa de la fantasía. 
chicas". "Todos tenemos una torre en nuestro interior. Parte de nosotros permanece en esa torre interior" 19 . Y en este momento, me temo que la conclusión de esta ponencia se universaliza. Porque hemos de advertir que, de manera maravillosa, se produce finalmente una confluencia entre hombres y mujeres escritores. Partiendo cada uno de sus propias realidades y límites, los autores que actualmente se esfuerzan en apostar por la fantasía en su novelística están logrando no solamente superar los moldes habituales literarios, sino también los moldes culturales, sociales, entre los que incluimos la siempre pesada distinción de géneros masculino-femenino, distinción que se incorpora como una más dentro del carácter múltiple del individuo. Por tanto, logran proponer otras realidades en varios niveles, en varios ámbitos. Les recomiendo, a modo de ejemplo, una lectura: El mundo en la era de Varick, de Andrés Ibáñez (Siruela, 1999).

En este punto, me parece que la cuestión de la literatura escrita por mujeres o por hombres es algo que debe extinguirse por su propia razón de existencia. En el momento en el que, a modo de ascensus platónico, superemos la barrera de los sexos y nos atengamos tan sólo a las voces que surgen del texto, podremos reconocer en ellas, como quería Rilke a través del $\operatorname{amor}^{20}$, a las personas. Quizás así superemos muchas discusiones actuales.

Parece necesario, pues, distinguir los ecos de las voces y atender a esta defensa de la fantasía como posible sendero de la búsqueda de nuevas voces narrativas, de revelar los huecos ocultos de nuestra realidad, porque "todo libro debe ser una ventana a lo desconocido" (Espido Freire); podríamos reflexionar también acerca de lo que nos sugiere Ana Rossetti sobre la razón, la mirada y la verdad de las cosas. Aún existen muchos mapas demasiado acotados que nos guían y avisan de que más allá no existe nada bueno, razonable. De que hay monstruos. Aún hay muchas fronteras que superar y la de la razón pura y sus razones es una de ellas. Esto es algo que ya entendió nuestra princesa, aquella que nunca fue rescatada por su caballero Jorge, sino que fue ella quien lo rescató con su propia voz y su imaginación y nos dejó, para más señas, una historia tan fantástica como verdadera. Por ello,

"No se debe temer alterar la razón para que se exprese lo intuido; ni penetrar más allá de lo que los sentidos captan para reconocer lo esencial; porque más allá no hay monstruos, sino una mirada distinta para comprender mejor el misterio"21 (...) "Quizá, para la razón, sólo pueda demostrarse lo que está sujeto a datos, fechas, peso, dimensión y cantidad. Quizás la realidad sea eso: materia y, por tanto, sujeta a mudanzas. Pero la verdad es invisible. Es una soberana de la que se puede desertar, pero no se la puede destronar ni destruir. Por eso, cuando una historia, por muy insólita que sea, se expande y permanece confirma su autenticidad imperecedera en el territorio de lo esencial, más allá del reino de la percepción.

$Y$, además, esta historia le salió preciosa a la doncella"22.

19 “La niña extranjera”, p. 45.

20 “Esta humanidad de la mujer, madurada en los dolores y las humillaciones, saldrá a luz cuando la mujer haya mudado los convencionalismos de lo exclusivamente femenino, en las metamorfosis de su condición social; y los hombres, que aún no sienten llegar esto, se verán sorprendidos y vencidos. (...) Un día la joven será, y será la mujer, y sus nombres no significarán más lo mero contrario de lo masculino, sino algo por sí, algo por lo cual no se piense en ningún complemento ni límite, sino nada más que en vida y ser: el ser humano femenino.” Rainer María Rilke, Cartas a un joven poeta, Carta VII, 14 de mayo de 1904.

21 “Más allá no hay monstruos”, p. 84.

22 “Más allá no hay monstruos”, p. 62. 


\section{BIBLIOGRAFÍA}

\section{Obras citadas y comentadas}

- $\quad$ CASTIGLIONE, Baltasar de.- El Cortesano, Madrid, Cátedra, 1994.

- FREIRE, Espido.- "Defensa de la fantasía”, transcripción de la conferencia pronunciada para la fundación Aula de Cultura en diversos lugares de España durante el año 2000.

- $\quad$ FREIRE, Espido.- Primer amor, Madrid, Temas de Hoy, 2000.

- HICKEY PELLIZONI, Margarita.- Poesías varias sagradas, morales y profanas o amorosas: con dos poemas épicos (Tomo I). En la dirección electrónica:

- $\quad$ http://cervantesvirtual.com/servlet/SirveObras/875426559626736629127639/p0000001.htm\#1

- $\quad$ IBÁÑEZ, Andrés.- El mundo en la era de Varick, Madrid, Siruela, 1999.

- $\quad$ KHUN, Thomas S. : La revolución copernicana, Planeta - De Agostini, Barcelona, 1994

- $\quad$ LEÓN, Fray Luis.- La perfecta casada, Madrid, Espasa-Calpe, 1992.

- $\quad$ MARTÍN GAITE, Carmen.- Nubosidad variable, Madrid, Anagrama, 2000.

- $\quad$ MARTÍNEZ DE TOLEDO, Alfonso.- Corbacho, Madrid, Cátedra, 1987.

- $\quad$ MATUTE, Ana María.- La torre vigía, Lumen, 1986.

- $\quad$ MATUTE, Ana María.- Olvidado Rey Gudú, Madrid, Espasa-Calpe, 1996.

- $\quad$ MATUTE, Ana María.- Aranmanoth, Madrid, Espasa-Calpe, 2000.

- MATUTE, Ana María.- "En el Bosque”. Transcripción del Discurso de ingreso en la RAE, edición electrónica: http://www.aragonesasi.com/casal/matute/matute01.htm

- PARDO BAZÁN, Emilia.- "Prólogo” en STUART MILL: La esclavitud femenina,edición electrónica: http://cervantesvirtual.com/servlet/SirveObras/430346828416175406227894/p0000001.htm\#1

- $\quad$ RILKE, Rainer María.- Cartas a un joven poeta, Madrid, Alianza, 1997.

- $\quad$ ROSSETTI, Ana.- Una mano de santos, Madrid, Siruela, 1997.

- $\quad$ ZAYAS Y SOTOMAYOR, María de.- Novelas amorosas y ejemplares, Madrid, Cátedra, 2000.

\section{Bibliografía consultada}

- $\quad$ FREIXAS, Laura.- Literatura y mujeres, Barcelona, Destino, 2000.

- $\quad$ WOOLF, Virginia.- Una habitación propia, Barcelona, Seix Barral, 1997.

- ZAVALA, Iris María (coord).- Breve historia feminista de la literatura española (en lengua castellana), volúmenes IV y V, Barcelona, Anthropos, 1997-1998.

- HARO CORTÉS, Marta y RODRÍGUEZ CUADROS, Evangelina.- “Introducción” en Entre la rueca y la pluma. Novela de mujeres en el Barroco, Madrid, Biblioteca Nueva, 1999, pp. 11-138.

- $\quad$ MARTÍN GAITE, Carmen.- Desde la ventana, Madrid, Espasa-Calpe, 1987.

- NAVARRA, Ana.- "Introducción” en Antología poética de escritoras de los siglos XVI y XVII, Madrid, Castalia, 1989, pp. 7-63.

- $\quad$ FERRERAS, Juan Ignacio.- La novela en el siglo XVIII, Madrid, Taurus, 1987.

- $\quad$ FERRERAS, Juan Ignacio.- La novela en el siglo XIX, 2 vols., Madrid, Taurus, 1990. 


\section{Álvaro LLosa Sanz}

\section{Fantázia és hang: képzelt univerzumok keresése és a fikció meghódítása néhány kortárs írónő munkásságában}

A történelem során a női írók munkássága több változáson ment át, miközben azt számos kritika is érte. A kezdetben komoly irodalmi mü megírására biológiailag lehetetlennek és elfogadhatatlannak tartott nő később alkalmasnak találtatott bizonyos témák, müfajok és közhelyek papírra vetésére, mígnem később eljutunk egy íróként is elismert, saját női mivoltában független és elfogadott nőhöz. E folyamat, mely gyakran maga is megjelenik az írónők elbeszéléseiben és szövegeiben, máig sem fejeződött be. Napjainkban, a 21. század elején, néhány, különböző generációhoz tartozó spanyol írónő (Ana María Matute, Ana Rosetti, Espido Freire), úgy tünik, végre pontot akar tenni e folyamat végére. Mindehhez segítségül hívják az iróniát, a fantázián keresztül egy saját hangot keresnek, képzelt világokat fedeznek fel. 